\title{
Life on the outside: role of biofilms in environmental persistence of Shiga-toxin producing Escherichia coli
}

\author{
Philippe Vogeleer ${ }^{1}$, Yannick D. N. Tremblay ${ }^{1}$, Akier A. Mafu ${ }^{2}$, Mario Jacques $^{1}$ and Josée Harel ${ }^{1 *}$ \\ Groupe de Recherche sur les Maladies Infectieuses du Porc, Département de Pathologie et Microbiologie, Faculté de Médecine Vétérinaire, Centre de Recherche \\ d'Infectiologie Porcine et Avicole, Université de Montréal, St-Hyacinthe, OC, Canada \\ 2 Food Research and Development Centre, Agriculture and Agri-Food Canada, St-Hyacinthe, OC, Canada
}

\section{Edited by:}

Sebastien P. Faucher, McGill

University, Canada

Reviewed by:

Kevin Mason, The Ohio State

University, USA

Ulrike Kappler, University of

Queensland, Australia

\section{*Correspondence:}

Josée Harel, Faculté de Médecine Vétérinaire, Université de Montréal, 3200 Sicotte, St-Hyacinthe, QC J2S 7C6, Canada

e-mail: josee.harel@umontreal.ca
Escherichia coli is a heterogeneous species that can be part of the normal flora of humans but also include strains of medical importance. Among pathogenic members, Shiga-toxin producing E. coli (STEC) are some of the more prominent pathogenic E. coli within the public sphere. STEC disease outbreaks are typically associated with contaminated beef, contaminated drinking water, and contaminated fresh produce. These water- and food-borne pathogens usually colonize cattle asymptomatically; cows will shed STEC in their feces and the subsequent fecal contamination of the environment and processing plants is a major concern for food and public safety. This is especially important because STEC can survive for prolonged periods of time outside its host in environments such as water, produce, and farm soil. Biofilms are hypothesized to be important for survival in the environment especially on produce, in rivers, and in processing plants. Several factors involved in biofilm formation such as curli, cellulose, poly-N-acetyl glucosamine, and colanic acid are involved in plant colonization and adherence to different surfaces often found in meat processing plants. In food processing plants, contamination of beef carcasses occurs at different stages of processing and this is often caused by the formation of STEC biofilms on the surface of several pieces of equipment associated with slaughtering and processing. Biofilms protect bacteria against several challenges, including biocides used in industrial processes. STEC biofilms are less sensitive than planktonic cells to several chemical sanitizers such as quaternary ammonium compounds, peroxyacetic acid, and chlorine compounds. Increased resistance to sanitizers by STEC growing in a biofilm is likely to be a source of contamination in the processing plant. This review focuses on the role of biofilm formation by STEC as a means of persistence outside their animal host and factors associated with biofilm formation.

Keywords: STEC, biofilm, sanitizers, processing plant, environment

\section{INTRODUCTION}

Escherichia coli is a diverse species of bacterium that includes members of the normal commensal flora of humans and animals but also pathogenic strains of veterinary and medical importance. Pathogenic members are usually classified in two major groups: intestinal E. coli (InPEC) and extraintestinal E. coli (ExPEC). The latter group is typically responsible for urinary tract infections [uropathogenic E. coli (UPEC)], neonatal sepsis, and meningitis in humans and various infectious diseases in animals including mastitis (Kaper et al., 2004; Clements et al., 2012). InPEC are classically divided in 8 sub-groups based on the diseases they cause, their virulence factors, and phylogeny. These 8 pathotypes are: adherent-invasive E. coli (AIEC) associated with Crohn's disease, diffusely adherent E. coli (DAEC), enteroaggregative E. coli (EAEC), enterotoxigenic E. coli (ETEC), enteropathogenic E. coli (EPEC), Shiga-toxin producing E. coli (STEC) that includes enterohemorrhagic E. coli (EHEC), and enteroinvasive E. coli (including Shigella) (EIEC) (Kaper et al., 2004; Clements et al., 2012). The characteristics of each pathotype have been described in several reviews (Kaper et al., 2004; Croxen and Finlay, 2010; Clements et al., 2012).

STEC are worldwide water- and food-borne pathogens and are some of the more prominent pathogenic E. coli within the public sphere (Etcheverria and Padola, 2013). Cattle are an important animal reservoir of STEC and this colonization is typically asymptomatic (Ferens and Hovde, 2011). STEC can also be shed in the feces of sheep, goats, turkeys, and pigs (Heuvelink et al., 1999; Booher et al., 2002; Cornick and Helgerson, 2004; Vu-Khac and Cornick, 2008; Best et al., 2009; La Ragione et al., 2009). STEC disease outbreaks are typically associated with contaminated beef; however unpasteurized milk, contaminated drinking water, contaminated fresh produce, and unpasteurized apple cider have also been implicated (Ferens and Hovde, 2011). In addition to living within animal reservoirs, STEC can persist for prolonged periods of time in the environment, such as in water and farm soil. For example, EHEC can survive for periods greater than 8 months in water contaminated with bovine feces (Ferens and Hovde, 2011). 
STEC are also a major concern in food-processing plants and contamination of beef carcasses with STEC may occur during different stages of processing such as slaughtering, dressing, chilling or cutting (Bacon et al., 2003; Koutsoumanis and Sofos, 2004). Therefore, populations of contaminating STEC are likely present on the surface of several pieces of equipment associated with slaughtering and processing. These pieces of equipment may potentially contaminate unadulterated carcasses and fresh meat products (Gill and McGinnis, 2000; Barkocy-Gallagher et al., 2001; Gill et al., 2001; Tutenel et al., 2003). The presence of STEC in beef and food processing plants has been well documented and it has been suggested that the ability to form biofilms on different surfaces is responsible for the distribution and persistence of STEC in meat processing plants (Carpentier and Cerf, 1993; Dewanti and Wong, 1995; Aslam et al., 2004; Rivera-Betancourt et al., 2004). In this review, we will explore the role of biofilm formation by STEC as a means of persistence outside their animal hosts and factors associated with biofilm formation.

\section{GENETIC DIVERSITY OF STEC}

The predominant STEC serotype associated with outbreaks is O157:H7. Since it was one of the first serotypes identified as causing hemolytic uremic syndrome (HUS) and the most severe illness, EHEC O157:H7 is the most commonly reported STEC serotype in the media (Etcheverria and Padola, 2013). However, other clinically relevant serotypes have been identified and are commonly called the "the big six," these include serotypes O26, O45, O103, O111, O121, and O145 (Wang et al., 2012). Other serotypes (e.g., O113:H21 and O91:H21) generally do not cause outbreaks but have been associated with sporadic cases of HUS (Karmali et al., 2003). Additionally, a new type of emerging STEC strain was identified after the large HUS outbreak in Germany in 2011 (Frank et al., 2011). This strain belongs to the serotype O104:H4 and combines the chromosomal backbone of a typical EAEC strain with the bacteriophage encoding Stx2 from STEC (Scheutz et al., 2011). The stx2 gene was presumably acquired via horizontal gene transfer. This atypical Shiga-toxin producing enteroaggregative E. coli (STEAEC) strain will not be covered in this review because it does not fit within the classic STEC pathotype.

In addition to serotype diversity within the STEC pathotype, genetic diversity in the O157:H7 serotype is gaining ground as a source of variation in virulence between strains (Bono et al., 2007; Manning et al., 2008; Zhang et al., 2010; Shringi et al., 2012). This phenomenon is observed with different E. coli O157 strains, where there is a significant association between clades and the severity and duration of disease (Fukushima et al., 1999; Grant et al., 2008; Manning et al., 2008). Furthermore, geographical distribution also appears to influence the phylogeny of E. coli O157 populations and recent findings suggest divergent evolution of EHEC O157 in Australia and the United States (Mellor et al., 2013). Despite this diversity, most studies on STEC biofilm formation are performed with the sequenced reference strain EDL933 that was isolated from meat associated with a USA hemorrhagic colitis outbreak in 1982 (Perna et al., 2001; Manning et al., 2008). Therefore, some of the conclusions may only reflect
North American strains rather than strains isolated from other continents.

\section{BIOFILM FORMATION BY STEC}

Generally, bacteria do not live freely in suspension (planktonic cells), but in complex communities called biofilms. Biofilms are aggregates of microorganisms (bacteria, fungi, algae, or protozoa) enclosed in a self-produced extracellular polymeric matrix that are attached to a biotic or abiotic surface (Costerton et al., 1999; Hall-Stoodley and Stoodley, 2009; Jacques et al., 2010). Biofilms protect bacteria from several challenges including desiccation, bacteriophages, amoebae, and biocides used in industrial processes (Costerton et al., 1999). With respect to E. coli biofilm formation, studies have mostly been performed with K12 strains and have been reviewed in several publications (Beloin et al., 2008; Wood, 2009). EDL933 and MG1655 share a core set of genes, including some genes involved in biofilm formation; as a result, data obtained using K12 strains are often used to infer function for STEC strains. However, such inferences are not always appropriate because there are key differences between the genomes of K12 and EDL933 including the presence of O-islands, lack of type 1 fimbriae production, and the presence of single nucleotide polymorphisms (SNP) (Perna et al., 2001; Roe et al., 2001; Welch et al., 2002; Zhang et al., 2006; Chen et al., 2013). Additionally, the expression and activity of several factors that must act at specific times and at various locations in the biofilm are required for proper biofilm formation (Beloin et al., 2008; Wood, 2009).

\section{DIFFERENCES BETWEEN STEC AND K12 THAT MAY INFLUENCE BIOFILM FORMATION}

As stated above, there are key differences between K12 and STEC strains that may have major influences on biofilm formation. For example, the EDL933 genome possesses $177 \mathrm{O}$-islands (OI), several of which encode fimbrial adhesins (Perna et al., 2001). However, the presence of a gene in a genome does not guarantee its expression. As an example, type 1 fimbriae are associated with biofilm formation in K12 strains, but a deletion in the fim regulatory region abolished type 1 fimbriae expression in E. coli O157:H7 (Roe et al., 2001; Beloin et al., 2004). Therefore, type 1 fimbriae do not play a role in biofilm formation by $E$. coli O157:H7. These data highlight the fact that findings for K12 do not always represent biological processes for all E. coli subtypes. Furthermore, many groups have demonstrated that STEC biofilm formation is more dependent on the strain than the serotype. This could be explained by the presence of SNP that result in premature stop codons in genes encoding adhesins or RpoS, the stationary phase sigma factor that is important for biofilm formation and regulation (Zhang et al., 2006).

In addition to differences at the genomic level, there are key differences in the transcript profiles of K12 and EHEC strains for biological processes involved in the interactions with lettuce leaves (Fink et al., 2012) including genes that may be involved in biofilm formation. Differences in the transcriptomes of K12 and STEC strains could be explained by the presence of additional regulators encoded within genomic islands and changes in promoter regions. For example, the genomic island OI-47 of E. coli $\mathrm{O} 157: \mathrm{H7}$ 
contains a gene, $v m p A$, coding for a c-di-GMP phosphodiesterase that is specific for EHEC O157:H7 and VmpA was shown to influence the regulation of biofilm formation (Branchu et al., 2013). Furthermore, recent findings have highlighted differences in EHEC and EPEC promoter regions that result in the differential regulation of an outer-membrane protease (Thomassin et al., 2012). Taken together, these differences indicate that biofilm data obtained with K12 strains or other pathotypes are not always directly relevant to STEC strains. Therefore, it is important that biofilm formation be studied in STEC.

\section{STEPS IN BIOFILM FORMATION}

Biofilm formation requires specific steps and is typically described as a four-step process: initial contact, attachment, maturation, and dispersion (Figure 1).

\section{INITIAL CONTACT}

The first step in biofilm formation is reversible attachment to a surface; this is dependent on a balance of attractive and repulsive forces between the bacteria and the surface. Both environmental and bacterial factors are important for this interaction. Attachment is influenced by environmental conditions such as temperature, $\mathrm{pH}$, ionic force of the medium, and the rugosity of the surface in addition to bacterial properties such as hydrophobicity and motility (Fletcher, 1988; Pratt and Kolter, 1998; Danese et al., 2000). Furthermore, flagella-driven motility is considered to be an important factor during the initial step of biofilm formation by E. coli because K12 strains lacking flagella do not produce biofilms. Additionally, Chen and collaborators recently suggested that flagella-driven motility is also involved in biofilm formation of non-O157:H7 STEC (Chen et al., 2013).

\section{ATTACHMENT}

The second step in biofilm formation is irreversible attachment, which is often influenced by the presence of surface structures such as fimbrial adhesins (Beloin et al., 2004). Many classes of fimbriae have been implicated in the attachment of STEC to surfaces, including type 1 fimbriae, curli, type 4 pili, long polar fimbriae, and F9 fimbriae (Farfan and Torres, 2012).

\section{MATURATION}

The third step in biofilm formation is maturation. During biofilm maturation, bacteria continue to multiply and produce extracellular matrix. At this stage, the biofilm adopts a three-dimensional structure. This growth is mostly due to bacterium-bacterium interactions; several surface proteins and extracellular matrix components are involved in bacterial adhesion and biofilm architecture (Beloin et al., 2008). Two important factors for this step have been identified in E. coli: autotransporters for cell-cell interactions and exopolysaccharides (EPS) for the matrix architecture (Beloin et al., 2008).

\section{Important factors for biofilm maturation: autotransporters}

Autotransporter adhesins, which are members of the type $\mathrm{V}$ secretion system, have been associated with autoaggregation and biofilm formation. Screens in STEC strains have identified 9 autotransporter genes: chromosome encoded agn43, cah, ehaA, ehaB, ehaD, ehaG, saa, and $s a b$ and plasmid-encoded espP (Torres et al., 2002; Wells et al., 2008, 2009; Herold et al., 2009; Puttamreddy et al., 2010). The protein products of each of these genes have been associated with biofilm formation (Torres et al., 2002; Wells et al., 2008, 2009; Herold et al., 2009; Puttamreddy et al., 2010). A comparative study of three autotransporter genes (agn43, cah, and ehaA) among 51 STEC strains found that the presence of autotransporter genes within the genome was variable among STEC serotypes (Biscola et al., 2011). Specifically, agn43 was present at a higher frequency in non-O157 strains than O157 strains while the frequency of cah is higher in O157 strains compared to non-O157 strains (Biscola et al., 2011).

In addition to the autotransporter esp $P$, the pO157 plasmid encodes the enterohemolysin translocator $e h x D$, whose protein product was identified as a mediator of biofilm formation, indicating that $\mathrm{pO} 157$ is essential for biofilm formation (Puttamreddy et al., 2010). Large plasmids similar to pO157, encoding espP,

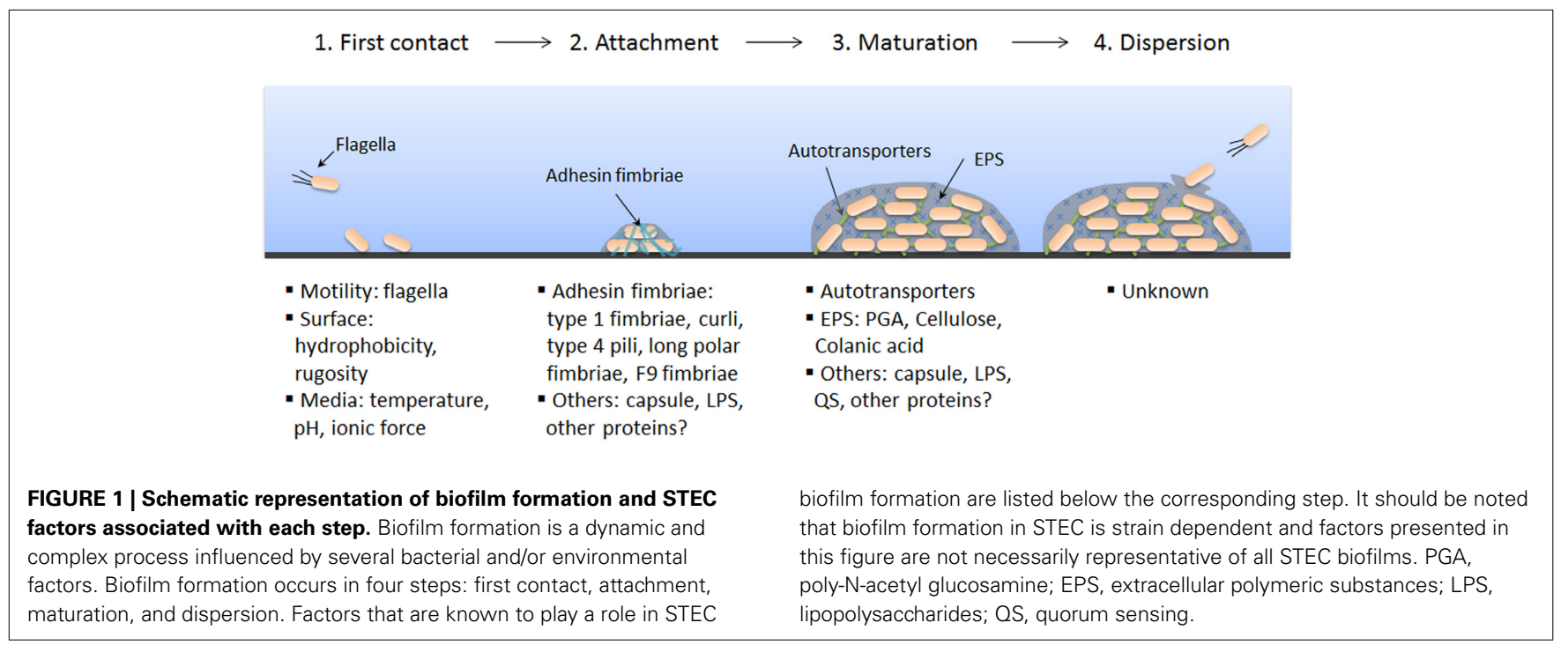


and $e h x D$ can also be found in many non-O157 EHEC strains (Brunder et al., 1999; Caprioli et al., 2005; Verstraete et al., 2013).

\section{Important factors for biofilm maturation: EPS}

The E. coli biofilm matrix can be composed of three different EPSs: poly-N-acetyl glucosamine (PGA), colanic acid, and/or cellulose. The genes encoding proteins that are involved in the synthesis of these polysaccharides are present in the genomes of STEC strains EDL933 and Sakai (Hayashi et al., 2001; Perna et al., 2001), however, their role in biofilm formation has not been directly established in these strains. However, O157:H7 mutants lacking genes encoding proteins needed to make PGA, cellulose, or colanic acid were unable to adhere to alfalfa sprouts (Matthysse et al., 2008). Furthermore, cellulose production was correlated with biofilm formation in O157 strains (Biscola et al., 2011; Lee et al., 2011). Cellulose production is, however, variable and dependent on both the bacterial strain and environmental conditions (Beloin et al., 2008). Colanic acid is produced by E. coli O157:H7, but there is limited data for other STEC serotypes (Beloin et al., 2008). The production of colanic acid protects E. coli O157:H7 against osmotic and oxidative stress, suggesting that colanic acid may be implicated in STEC biofilm formation, however, this remains to be tested directly (Yeh and Chen, 2004).

\section{Important factors for biofilm maturation: other factors}

Lipopolysaccharides (LPS) and capsules, which are surface structures, have been implicated in biofilm formation by E. coli. Mutations affecting LPS synthesis affect the ability of $E$. coli K12 strains to adhere to surfaces and form biofilms (Genevaux et al., 1999; Beloin et al., 2008). Similar observations were noted for E. coli O157:H7 strain EDL933, where $\mathrm{O}$-antigen transposon mutants could not form biofilms (Puttamreddy et al., 2010).

Capsules are known to mask bacterial surface adhesins and often have an indirect effect on biofilm formation (Schembri et al., 2004). According to Whitfield, capsule polysaccharides produced by some EHEC strains belong to the E. coli group 4 capsule, which is composed of the same sugar repeats as the LPS O-antigen and acetamido sugars in their repeat-unit structures (Whitfield, 2006). The impact of this capsule-type on biofilm formation by STEC has yet to be investigated. If the group 4 capsule has an impact on biofilm formation, its effect might be serotype specific given the diversity of O-antigen structures among STEC. Furthermore, the capsule is only expressed and present under specific laboratory conditions in EDL933 (Shifrin et al., 2008; Thomassin et al., 2013). Therefore, the role of the capsule in in vivo biofilm formation might be difficult to evaluate in an in vitro setting given that biofilm formation is also highly dependent on growth conditions.

Curli fimbriae are structures that aggregate on the surface of cells, they promote adhesion of E. coli to different human cells and biofilm formation on abiotic surfaces (Olsen et al., 1989; Ben Nasr et al., 1996; Vidal et al., 1998; Cookson et al., 2002; Uhlich et al., 2006). Curli expression in some STEC strains has been associated with biofilm formation on polystyrene and stainless steel surfaces (Cookson et al., 2002; Ryu et al., 2004b; Uhlich et al., 2006). However, curli expression, which is strain dependent and serotype independent, is not essential for biofilm formation (Wang et al., 2012). Additionally, curli can interact with cellulose to create networks resulting in the formation of a hydrophobic extracellular matrix (Zogaj et al., 2001; Gualdi et al., 2008). Curli are thought to facilitate initial cell-surface interactions and, subsequent cell-cell interactions (Cookson et al., 2002; Uhlich et al., 2006). Curli are encoded in two divergently transcribed operons: the $\operatorname{csgBA}$ operon encodes the structural components and the csgDEFG operon encodes the regulator $(\mathrm{CsgD})$ and the export machinery (CsgE-G) (Hammar et al., 1995). Both operons are found in the EHEC O157:H7 EDL933 and Sakai reference strains (Hayashi et al., 2001; Perna et al., 2001). Curli production is tightly controlled and complex; several transcriptional regulators (EnvZ/OmpR, CpxR, RcsCDB, RpoS, H-NS, IHF, Crl, and MlrA) and conditions (temperature, osmolarity, $\mathrm{pH}$, and oxygenation) control curli expression, which involves a network of interactions (Dorel et al., 1999; Prigent-Combaret et al., 2001; Brombacher et al., 2003; Gerstel et al., 2003; Jubelin et al., 2005; Vianney et al., 2005). The complex regulatory network of curli expression is thought to be fine-tuned to allow for the colonization of specific niches by E. coli (Prigent-Combaret et al., 2001; Kikuchi et al., 2005).

\section{Important factors for biofilm maturation: quorum sensing}

During the different steps of biofilm formation the bacterial cell population density fluctuates and gene expression varies. To coordinate gene expression, bacteria communicate using quorum sensing (QS) systems (Walters and Sperandio, 2006). QS systems are based on the secretion and/or recognition of signal molecules called autoinducers (AIs). Three types of AIs have been identified: AI-1, AI-2, and AI-3. Both AI-2 and AI-3 are produced, secreted, and recognized by E. coli strains including STEC (Walters and Sperandio, 2006). E. coli strains do not produce AI-1; however their genome encodes sdiA, the AI-1 sensor, which is a luxR homolog. This enables E. coli, including STEC strains, to recognize acyl-homoserine lactone (AHL), the signal molecule for AI-1, secreted by others bacterial species. In Sharma et al. (2010) demonstrated that SdiA acts as a repressor of curli and flagellar gene expression. An O157:H7 $\Delta$ sdiA strain had increased curli fimbriae and biofilm production, suggesting that the AI-1 system has a negative impact on biofilm formation (Sharma et al., 2010). LuxS, a metabolic enzyme also found in STEC strains, is primarily involved in the conversion of ribosyl-homocysteine into homocysteine and 4,5-dihydroxy-2,3pentanedione, which is the precursor for AI-2 (Schauder et al., 2001). Biofilm formation was enhanced when AI-2-like molecules were added to an O157:H7 luxS deletion strain (Lu et al., 2005; Bansal et al., 2008; Vikram et al., 2010). Furthermore, AI-3 and host-produced epinephrine/norepinephrine are recognized by the QseBC two component system (Walters and Sperandio, 2006). The addition of epinephrine and norepinephrine increases EHEC motility and biofilm formation, while the addition of indole attenuates these phenotypes (Bansal et al., 2007). Moreover, motility and biofilm formation by a $q s e C$ deletion strain were reduced by half when compared to the wild type strain (Yang et al., 2014). 


\section{DISPERSION}

The final step in biofilm formation is the detachment of bacteria from the biofilm and their dispersal, which contributes to the transmission of bacteria. Dispersal is a complex process that involves several environmental signals and effectors and no single dispersal mechanism is used by all bacterial species. As described above, bacteria generally switch from a planktonic to a biofilm lifestyle by sensing environmental changes. Biofilm dispersal has recently been reviewed in detail (Kaplan, 2010). Dispersal is the least understood step in biofilm formation for all bacterial species and has not been investigated for STEC (Figure 1). In E. coli other than STEC, modulation of crucial surface structures, such as type IV bundle-forming pili (BFP) in EPEC and aggregative adherence fimbriae (AAFs) in EAEC, results in the detachment of bacteria from the biofilm and surface (Knutton et al., 1999; Sheikh et al., 2002; Velarde et al., 2007). For example in EAEC, positively charged AAFs extend away from the surface of the bacterial cell to mediate surface-adherence when dispersin is produced, because dispersin binds to and neutralizes LPS charge (Sheikh et al., 2002; Velarde et al., 2007). When dispersin is down-regulated, the positively charged AAFs collapse on the bacterial surface due to their interaction with negatively charged LPS. As a consequence of this collapse, AAFs no longer adhere to surfaces and the biofilm disperses (Sheikh et al., 2002; Velarde et al., 2007). Mechanisms involved in biofilm detachment are of increased interest, because the understanding of these mechanisms could lead to the development of clinical or industrial tools to remove biofilms.

\section{SURVIVAL IN THE ENVIRONMENT: IS IT BIOFILM MEDIATED?}

STEC contamination of the environment and food-processing plant can occur several different ways (Figure 2). STEC are typically shed in the feces of cattle and this will contaminate the hide and farm environment (Elder et al., 2000; Aslam et al., 2003). STEC that are present in feces can contaminate manure and, consequently, soils either through manure runoff or manure applied to fields (Gagliardi and Karns, 2000; Solomon et al., 2002; Van Elsas et al., 2011). At this stage, STEC may persist and grow on fresh produce such as lettuce and can be internalized and survive within plant tissue via a mechanism that is not fully understood (Seo and Frank, 1999; Jeter and Matthysse, 2005; Tyler and Triplett, 2008). Furthermore, manure applied to fields often ends up in ground or surface water through runoff; this water is often used to irrigate fields and water crops (Ribeiro et al., 2012). As a consequence, fields and crops that were not treated with manure can become contaminated with STEC. All of these contribute to the contamination and spread of STEC in the environment. STEC can survive in soil, on fresh produce, manure, and river water, which is hypothesized to be associated with the ability of STEC to form biofilms.

\section{SOIL AND MANURE}

Survival of E. coli O157:H7 in soil and manure is greatly influenced by microbial diversity; EHEC survival is at its highest when diversity is low (Vidovic et al., 2007; Van Overbeek et al., 2010; Ibekwe et al., 2011; Van Elsas et al., 2011). On one hand, survival

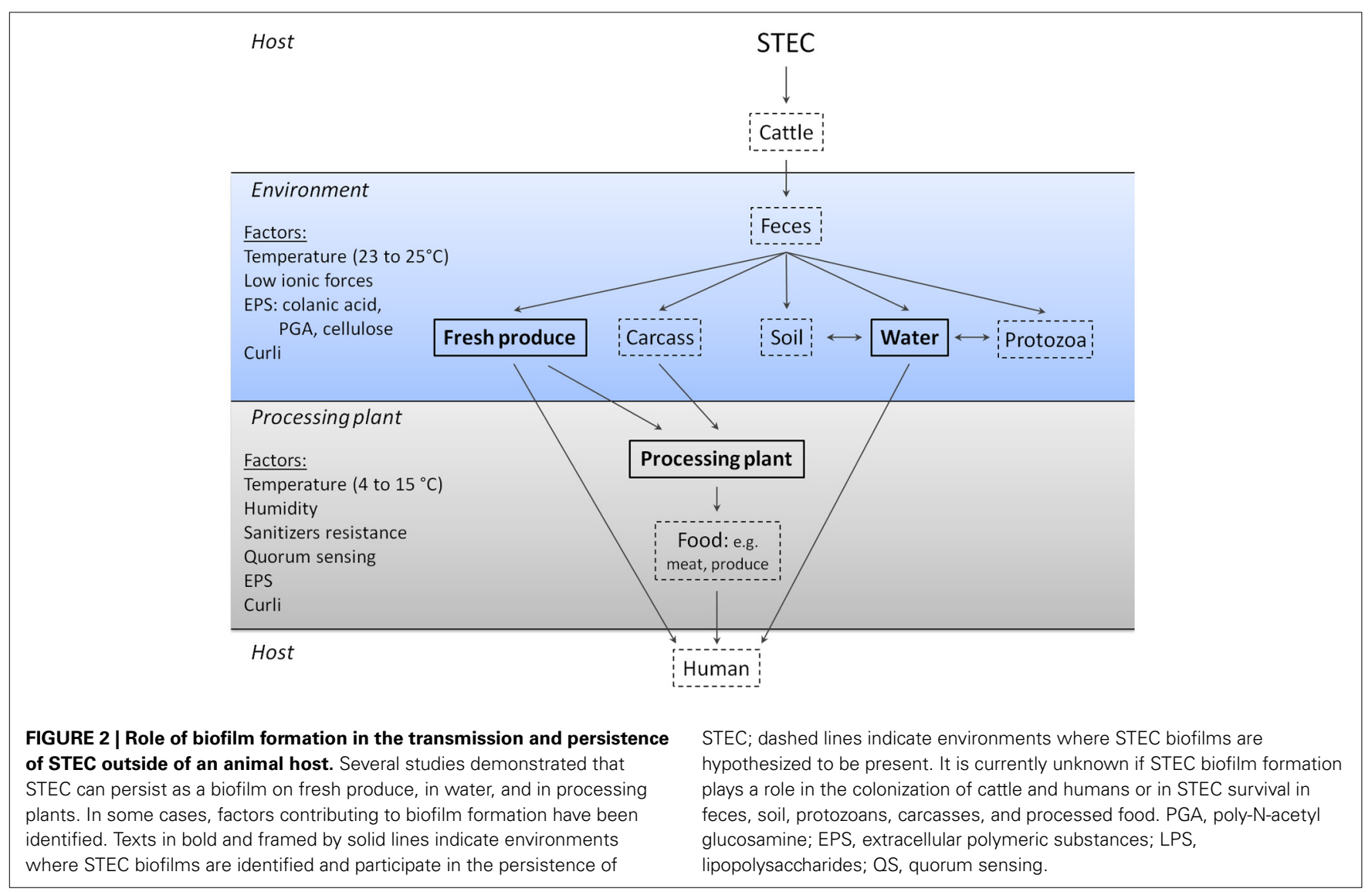


of STEC within soil and manure is also hypothesized to be associated with the absence of various protozoa that graze on STEC (Ravva et al., 2010). On the other hand certain protozoa are proposed to act as a transmission vehicle for EHEC (Chekabab et al., 2012). Taken together these results strongly suggest that STEC survival is influenced by the environmental microcosm. There is, however, little evidence to indicate that STEC are able to form or integrate into biofilms within manure, soil, or in the farm environment. Therefore, there is a need for studies that investigate the role of biofilms in promoting STEC survival within these environments.

\section{WATER}

Biofilms containing STEC have been detected in freshwater streams that drain or are connected to agricultural land (Cooper et al., 2007; Maal-Bared et al., 2013). It is unknown if STEC can act as the pioneer bacteria in environmental biofilms, but this possibility is unlikely because periphytic E. coli isolates appear to form biofilms more readily than human and/or bovine isolates (Moreira et al., 2012). The presence of STEC in environmental biofilms may be explained by the finding that biofilm negative E. coli $\mathrm{O} 157: \mathrm{H7}$ strains are able to integrate into pre-established biofilms formed by other E. coli strains (Uhlich et al., 2010). Therefore, it is likely that STEC can integrate into pre-existing biofilms.

Mixed-species biofilms formed in rivers and river sediments are also of particular interest because they provide ample opportunity for genetic exchange between bacteria (Maal-Bared et al., 2013). Furthermore, the environment within the biofilm is suitable for the transduction of stx-encoding phages carried by STEC (Solheim et al., 2013). The transfer of these phages is responsible for the spread of stx genes among E. coli species. Such genetic exchanges could contribute to the emergence of new pathogenic E. coli and give rise to the next outbreak strain.

\section{FRESH PRODUCE}

Several genes and/or structures associated with biofilm formation have been identified as important factors for plant colonization by STEC. For example, PGA, cellulose, and colanic acid play a role in E. coli $\mathrm{O} 157$ binding to sprouts and tomato root segments (Matthysse et al., 2008). Furthermore, PGA is essential for binding to sprouts and cellulose and colanic acid increase the efficiency of this attachment (Matthysse et al., 2008). These findings provide evidence that the biofilm matrix associated polysaccharides are crucial for attachment to plants. In addition, these EPSs are expressed under environmental conditions [i.e., room temperature $\left.\left(23-25^{\circ} \mathrm{C}\right)\right]$, in low-ionic-strength medium, and during nutrient limitation by several E. coli strains (Gottesman and Stout, 1991; Matthysse et al., 2008). The expression of matrix polysaccharides in environments similar to those encountered in the presence of fresh produce further supports the likelihood that biofilm formation plays a role in STEC survival on produce.

Curli fimbriae improve the adherence of E. coli O157:H7 to spinach leaves, and interestingly, the improved adherence was found to be independent of cellulose production (Macarisin et al., 2012). Biofilm modulation genes ( $y c f R$ and $y b i M)$ are also significantly up-regulated when E. coli O157:H7 interacts with lettuce roots (Hou et al., 2013). Furthermore, a $\Delta y c f R$ strain was unable to attach to or colonize lettuce roots (Hou et al., 2013). Taken together these studies suggest that certain factors involved in biofilm formation improve the environmental fitness of STEC, especially in the context of plant colonization.

\section{BIOFILMS AND PROTOZOA}

Protozoans living in soil, manure, and rivers probably prey on STEC living in the environment (Ravva et al., 2010). Recent studies have shown that EDL933 can survive in Acanthamoeba castellanii and replicate within Acanthamoeba polyphaga, protozoa commonly found in soil, water, and fecal slurry (Barker et al., 1999; Chekabab et al., 2012). It was suggested that such protozoa could also serve as a transmission vehicle for EHEC (Chekabab et al., 2012). In support, the presence of the Stx-encoding prophage increases the survival of STEC isolates in the presence of Tetrahymena pyriformis or Tetrahymena thermophila (Steinberg and Levin, 2007; Mauro et al., 2013). Protozoa are known to graze on biofilms and ciliates and flagellates differently influence biofilm communities (Wey et al., 2012). For example, Glaucoma and Tetrahymena species (ciliates), expel vesicles containing viable E. coli O157:H7, whereas Colpoda steinii and Acanthamoeba palestinensis (flagellates) do not (Gourabathini et al., 2008). Furthermore, protozoans graze less on biofilm communities than on their planktonic cells, suggesting that biofilms may offer some protection from protozoan predation (Wey et al., 2012).

\section{STEC BIOFILMS IN PROCESSING PLANTS, A POTENTIAL SOURCE OF MEAT AND PRODUCE CONTAMINATION}

In addition to forming biofilms under environmental conditions and on plants, STEC are able to form biofilms on different surfaces often found in meat processing plants, such as stainless steel, polystyrene, glass, polyurethane, and high-density polyethylene (Dewanti and Wong, 1995; Dourou et al., 2011; Nesse et al., 2013). The introduction of contaminated food into processing plants results in the spread of STEC and contamination. As an example, it was estimated that the prevalence of E. coli $\mathrm{O} 157$ on cattle entering the slaughter floor may range from 10 to $>70 \%$ (Woerner et al., 2006). In the meat industry, contamination of surfaces with STEC can be traced to the entry of contaminated hides. Fecal contamination of hides occurs both directly and indirectly during cattle production and transit. Currently, disinfection protocols are used to try to limit the entry of STEC into slaughterhouses and processing plants. Despite the common use of disinfection protocols, STEC contamination of food still occurs, which according to the Center for Disease Control and Prevention (CDC) and Public Health Agency of Canada (PHAC) shows that disinfections protocols do not always prevent contamination (http://www.cdc.gov/ ecoli/ and http://www.phac-aspc.gc.ca/fs-sa/fs-fi/ecoli-eng.php). The persistence of STEC in the presence of disinfectants gives rise to the probability that STEC survive and grow within a biofilm in processing plants (Stopforth et al., 2003; Ryu et al., 2004a; Uhlich et al., 2006; Fouladkhah et al., 2013). In this section we will focus on STEC biofilm formation and associated factors in processing plants.

In the processing plant environment, temperatures are normally controlled and maintained between 4 and $15^{\circ} \mathrm{C}$. Many 
studies have shown that STEC are able to grow in a biofilm within this temperature range (Dourou et al., 2011; Fouladkhah et al., 2013; Nesse et al., 2013). For example, E. coli O157:H7 is able to colonize surfaces in contact with beef at $15^{\circ} \mathrm{C}$ (non-production hours temperature) and $4^{\circ} \mathrm{C}$ (production hours temperature) (Dourou et al., 2011; Fouladkhah et al., 2013). Interestingly, E. coli O157:H7 attachment increased at $4^{\circ} \mathrm{C}$ over time in the presence of a fat-lean tissue homogenate (Dourou et al., 2011). Furthermore, E. coli O157:H7 EDL933 is able to adhere and produce a dense biofilm on surfaces that are not favorable for its attachment when collagen I is present, which is a muscle fibrous extracellular matrix protein (Chagnot et al., 2013). In addition to form biofilms in meat homogenates, E. coli O157:H7 is also able to form biofilms on stainless steel when grown in spinach leaf lysates (Carter et al., 2012). Environmental conditions such as temperature and culture broths containing meat or vegetable residues can affect the expression of genes controlled by QS. For example, it was shown that E. coli O157:H7 biofilms produce large amounts of AI-2 when cultured in pork, beef or spinach broth (Silagyi et al., 2009). Based on this evidence, it is possible that QS drives biofilm formation in meat processing plants.

Fouladkhah et al. showed that the use of quaternary ammonium compound-based and peroxyacetic-based chemical sanitizers on biofilms that had matured for 1 week were more effective at $4^{\circ} \mathrm{C}$ than $25^{\circ} \mathrm{C}$. However, these commercial sanitizers used at concentrations recommended to kill planktonic STEC were not able to kill or remove STEC biofilms from stainless steel surfaces (Fouladkhah et al., 2013). Furthermore, curli fimbriae, due to their amyloid properties, can protect bacteria from antibacterial agents like chlorine or quaternary ammonium sanitizers (Uhlich et al., 2006; Wang et al., 2012). It has been shown that tolerance of sanitizers by STEC in biofilms do not depends on serotype but on strain (Wang et al., 2012). It was also shown that at 100\% relative humidity (RH), E. coli O157:H7 biofilms were more resistant to sanitizers than at lower RH (Bae et al., 2012). Furthermore, large biofilms were more resistant to cleaning and disinfection protocols and repeated treatment could results in the presence of viable but non-culturable E. coli O157:H7 that were able to regrow as a biofilm on polyurethane (Marouani-Gadri et al., 2010). Taken together, these data indicate that sanitizer efficacy may be limited against STEC growing within a biofilm community.

Interestingly, non-pathogenic bacteria isolated from processing plants, such as Comamonas testosterone, Acinetobacter calcoaceticus, Burkholderia caryphylli, and Ralstonia insidiosa, can initiate biofilm formation and may allow E. coli O157:H7 to integrate within a pre-formed biofilm, resulting in a mixed biofilm (Marouani-Gadri et al., 2009a; Habimana et al., 2010; Liu et al., 2014). For example, C. testosteroni can enhance the ability of E. coli O157:H7 to form biofilms (Marouani-Gadri et al., 2009a). The presence of $C$. testosteroni within the biofilm did, however, decrease the number of colony forming units of E. coli O157:H7 following chemical treatment when compared to chemical treatment of a single species E. coli O157:H7 biofilm (Marouani-Gadri et al., 2010). These data suggest that the presence of nonpathogenic bacterial species has a large influence on the ability of STEC to persist within the processing plant; due to the potential impact of these data, these findings merit further investigation.
The ability to secrete EPS is related to biofilm formation on stainless steel surfaces, but it was shown that overproduction of the EPS inhibits the initial attachment of E. coli O157:H7 (Ryu et al., 2004a). EPS production may also protect E. coli O157:H7 from sanitizer treatments (Ryu et al., 2004a; Ryu and Beuchat, 2005). As with curli, EPS production may not be essential for biofilm formation on stainless steel by bacterial pathogens, including STEC. In addition, it has been shown that bacteria producing little or no EPS, including E. coli O157:H7 could colonize a mature biofilm formed by EPS-producing bacteria (Castonguay et al., 2006; Klayman et al., 2009; Dourou et al., 2011). Although sanitizers are able to reduce or totally kill STEC within biofilms, it is possible that recolonization by STEC or other bacteria will be easier if cleaning protocols do not completely remove the biofilm matrix.

In addition to the protection offered by the biofilm matrix against sanitizers, it is well established that for E. coli in general, a slow-growing and dormant subpopulations are highly tolerant to antibacterial treatments (Lewis, 2010). Cells from this subpopulation are called multidrug tolerant persister cells and are dormant variants that emerged from regular cells (Lewis, 2010). The emergence of persister cells occurs at a higher frequency within biofilm populations than planktonic populations (Lewis, 2010). This non-heritable variation could permit STEC to survive the sanitation process and these individual cells could remain encased in the biofilm matrix. These cells could then contribute to the reestablishment of a STEC biofilm or population within the processing plant.

\section{CAN STEC BIOFILMS BE REMOVED?}

It is known that STEC biofilms are more resistant to sanitizers than their planktonic counterparts (Wang et al., 2012). In recent years, many studies have focused on cleaning and disinfection procedures using physical and chemical methods. Three primary chemical compounds are used as sanitizers in the food service industry: chlorine-based cleaners, quaternary ammonium, and iodine sanitizers. Because of the toxicity of sanitizer residues and/or increased bacterial resistance to these decontamination reagents (Stopforth et al., 2003; Houari and Di Martino, 2007; Marouani-Gadri et al., 2009b; Hou et al., 2010; Wang et al., 2012), alternative molecules that are preferentially natural with low human and animal toxicity are being tested for their effect on biofilms.

Many essential oils have been shown to have good antibiofilm activity against food-borne pathogens (Giaouris et al., 2013). Perez-Conesa et al. have shown that surfactant micelles loaded with eugenol or carvacrol, two essential oils isolated from clove and thyme, are able to kill E. coli O157:H7 inside a biofilm. However, the biofilm matrix remains attached to the surface (Perez-Conesa et al., 2006, 2011), making reformation of a biofilm a dangerous possibility. While essential oils target cell viability, the best way to remove and prevent reformation of a biofilm on a surface is to degrade the EPS surrounding the bacteria by enzymatic treatment (Gibson et al., 1999; Lequette et al., 2010). A combination of an antimicrobial agent to kill cells within the biofilm with a food-grade agent able to remove the entire biofilm matrix could be a solution to reduce and potentially remove E. coli 
O157:H7 biofilms from processing plants. Others strategies such as bacteriophage treatments of E. coli $\mathrm{O} 157: \mathrm{H7}$ biofilms have also been investigated. The KH1 bacteriophage reduces the population of O157:H7 cells attached to stainless steel, but not those incased within a biofilm matrix (Sharma et al., 2005). The effect of combined techniques such as steam and lactic acid (Ban et al., 2012), aerosolized sanitizers (Park et al., 2012), UV and dry heat (Bae and Lee, 2012) were also studied and have the potential to control STEC O157:H7 biofilms found on surfaces present in the food industry. The best approach for controlling STEC biofilm should kill E. coli O157:H7 within the biofilm and remove the biofilm matrix from the contaminated surface. For example, a combination of steam and lactic acid were able to kill E. coli O157:H7 and remove the biofilm matrix from stainless steel surfaces (Ban et al., 2012). Further studies should investigate the effect of antibiofilm molecules on the dispersal of biofilms and also focus on mixed biofilms containing both non-pathogenic and STEC bacteria.

\section{CONCLUSION}

Contamination of the environment and processing plants with cow feces containing STEC is a major concern for food and public safety, especially since STEC can survive for prolonged periods of time outside its host. Biofilm formation appears to contribute significantly to STEC survival on produce, in rivers, and in processing plants. Several factors involved in biofilm formation such as curli, cellulose, PGA, and colanic acid are involved in plant colonization and attachment to different surfaces often found in meat processing plants. However, the factors involved in STEC survival within biofilms in rivers remain unknown. Furthermore, STEC biofilm formation on farms, in manure, and in soil has not been thoroughly explored despite the presence and persistence of STEC in these environments. The Stx toxin, which is a key factor in human host pathology, also appears to be an important factor for STEC survival against protozoan predation. In the food industry, resistance to sanitizers improves the ability of STEC to persist in the processing plant. Despite the development of new strategies to eradicate biofilms formed by food-borne pathogens, no effective solutions to remove STEC biofilms from surfaces have been identified. Therefore, future research should focus on the identification of factors promoting STEC survival, especially non-O157 STEC, and the persistence of STEC in environmental biofilms on the farm.

\section{ACKNOWLEDGMENTS}

We would like to thank Jenny-Lee Thomassin for proofreading and critical reading of the manuscript. We thank the Natural Sciences and Engineering Research Council of Canada (RGPIN SD-25120-09) to Josée Harel and Fonds de la recherche du Québec en nature et technologies to Josée Harel and Mario Jacques (FRQNT PT165375) and a studentship to Philippe Vogeleer from Fonds CRIPA (FRQNT Regroupements stratégiques 111946).

\section{REFERENCES}

Aslam, M., Greer, G. G., Nattress, F. M., Gill, C. O., and McMullen, L. M. (2004). Genotypic analysis of Escherichia coli recovered from product and equipment at a beef-packing plant. J. Appl. Microbiol. 97, 78-86. doi: 10.1111/j.13652672.2004.02277.x
Aslam, M., Nattress, F., Greer, G., Yost, C., Gill, C., and McMullen, L. (2003). Origin of contamination and genetic diversity of Escherichia coli in beef cattle. Appl. Environ. Microbiol. 69, 2794-2799. doi: 10.1128/AEM.69.5.2794-2799.2003

Bacon, R. T., Sofos, J. N., Kendall, P. A., Belk, K. E., and Smith, G. C. (2003). Comparative analysis of acid resistance between susceptible and multiantimicrobial-resistant Salmonella strains cultured under stationary-phase acid tolerance-inducing and noninducing conditions. J. Food Prot. 66, 732-740.

Bae, Y. M., Baek, S. Y., and Lee, S. Y. (2012). Resistance of pathogenic bacteria on the surface of stainless steel depending on attachment form and efficacy of chemical sanitizers. Int. J. Food Microbiol. 153, 465-473. doi: 10.1016/j.ijfoodmicro.2011.12.017

Bae, Y. M., and Lee, S. Y. (2012). Inhibitory effects of UV treatment and a combination of UV and dry heat against pathogens on stainless steel and polypropylene surfaces. J. Food Sci. 77, M61-M64. doi: 10.1111/j.1750-3841.2011.02476

Ban, G. H., Park, S. H., Kim, S. O., Ryu, S., and Kang, D. H. (2012). Synergistic effect of steam and lactic acid against Escherichia coli O157:H7, Salmonella Typhimurium, and Listeria monocytogenes biofilms on polyvinyl chloride and stainless steel. Int. J. Food Microbiol. 157, 218-223. doi: 10.1016/j.ijfoodmicro.2012.05.006

Bansal, T., Englert, D., Lee, J., Hegde, M., Wood, T. K., and Jayaraman, A. (2007). Differential effects of epinephrine, norepinephrine, and indole on Escherichia coli O157:H7 chemotaxis, colonization, and gene expression. Infect. Immun. 75, 4597-4607. doi: 10.1128/IAI.00630-07

Bansal, T., Jesudhasan, P., Pillai, S., Wood, T. K., and Jayaraman, A. (2008). Temporal regulation of enterohemorrhagic Escherichia coli virulence mediated by autoinducer-2. Appl. Microbiol. Biotechnol. 78, 811-819. doi: 10.1007/s00253008-1359-8

Barker, J., Humphrey, T. J., and Brown, M. W. (1999). Survival of Escherichia coli O157 in a soil protozoan: implications for disease. FEMS Microbiol. Lett. 173, 291-295. doi: 10.1111/j.1574-6968.1999.tb13516.x

Barkocy-Gallagher, G. A., Arthur, T. M., Siragusa, G. R., Keen, J. E., Elder, R. O., Laegreid, W. W., et al. (2001). Genotypic analyses of Escherichia coli O157:H7 and $\mathrm{O} 157$ nonmotile isolates recovered from beef cattle and carcasses at processing plants in the Midwestern states of the United States. Appl. Environ. Microbiol. 67, 3810-3818. doi: 10.1128/AEM.67.9.3810-3818.2001

Beloin, C., Roux, A., and Ghigo, J. M. (2008). Escherichia coli biofilms. Curr. Top. Microbiol. Immunol. 322, 249-289. doi: 10.1007/978-3-540-75418-3_12

Beloin, C., Valle, J., Latour-Lambert, P., Faure, P., Kzreminski, M., Balestrino, D., et al. (2004). Global impact of mature biofilm lifestyle on Escherichia coli K-12 gene expression. Mol. Microbiol. 51, 659-674. doi: 10.1046/j.13652958.2003.03865.x

Ben Nasr, A., Olsen, A., Sjobring, U., Muller-Esterl, W., and Bjorck, L. (1996). Assembly of human contact phase proteins and release of bradykinin at the surface of curli-expressing Escherichia coli. Mol. Microbiol. 20, 927-935. doi: 10.1111/j.1365-2958.1996.tb02534.x

Best, A., Clifford, D., Crudgington, B., Cooley, W. A., Nunez, A., Carter, B., et al. (2009). Intermittent Escherichia coli O157:H7 colonisation at the terminal rectum mucosa of conventionally-reared lambs. Vet. Res. 40, 9. doi: 10.1051/vetres:2008047

Biscola, F. T., Abe, C. M., and Guth, B. E. (2011). Determination of adhesin gene sequences in, and biofilm formation by, O157 and non-O157 Shiga toxinproducing Escherichia coli strains isolated from different sources. Appl. Environ. Microbiol. 77, 2201-2208. doi: 10.1128/AEM.01920-10

Bono, J. L., Keen, J. E., Clawson, M. L., Durso, L. M., Heaton, M. P., and Laegreid, W. W. (2007). Association of Escherichia coli O157:H7 tir polymorphisms with human infection. BMC Infect. Dis. 7, 98. doi: 10.1186/14712334-7-98

Booher, S. L., Cornick, N. A., and Moon, H. W. (2002). Persistence of Escherichia coli O157:H7 in experimentally infected swine. Vet. Microbiol. 89, 69-81. doi: 10.1016/S0378-1135(02)00176-1

Branchu, P., Hindre, T., Fang, X., Thomas, R., Gomelsky, M., Claret, L., et al. (2013). The c-di-GMP phosphodiesterase VmpA absent in Escherichia coli K12 strains affects motility and biofilm formation in the enterohemorrhagic O157:H7 serotype. Vet. Immunol. Immunopathol. 152, 132-140. doi: 10.1016/j.vetimm.2012.09.029

Brombacher, E., Dorel, C., Zehnder, A. J., and Landini, P. (2003). The curli biosynthesis regulator $\mathrm{CsgD}$ co-ordinates the expression of both positive and negative determinants for biofilm formation in Escherichia coli. Microbiology 149, 2847-2857. doi: 10.1099/mic.0.26306-0 
Brunder, W., Schmidt, H., Frosch, M., and Karch, H. (1999). The large plasmids of Shiga-toxin-producing Escherichia coli (STEC) are highly variable genetic elements. Microbiology 145(pt 5), 1005-1014. doi: 10.1099/13500872-1455-1005

Caprioli, A., Morabito, S., Brugere, H., and Oswald, E. (2005). Enterohaemorrhagic Escherichia coli: emerging issues on virulence and modes of transmission. Vet. Res. 36, 289-311. doi: 10.1051/vetres:2005002

Carpentier, B., and Cerf, O. (1993). Biofilms and their consequences, with particular reference to hygiene in the food industry. J. Appl. Bacteriol. 75, 499-511. doi: 10.1111/j.1365-2672.1993.tb01587.x

Carter, M. Q., Xue, K., Brandl, M. T., Liu, F., Wu, L., Louie, J. W., et al. (2012). Functional metagenomics of Escherichia coli O157:H7 interactions with spinach indigenous microorganisms during biofilm formation. PLoS ONE 7:e44186. doi: 10.1371/journal.pone.0044186

Castonguay, M. H., Van Der Schaaf, S., Koester, W., Krooneman, J., Van Der Meer, W., Harmsen, H., et al. (2006). Biofilm formation by Escherichia coli is stimulated by synergistic interactions and co-adhesion mechanisms with adherence-proficient bacteria. Res. Microbiol. 157, 471-478. doi: 10.1016/j.resmic.2005.10.003

Chagnot, C., Agus, A., Renier, S., Peyrin, F., Talon, R., Astruc, T., et al. (2013). In vitro colonization of the muscle extracellular matrix components by Escherichia coli O157:H7: the influence of growth medium, temperature and $\mathrm{pH}$ on initial adhesion and induction of biofilm formation by collagens I and III. PLoS ONE 8:e59386. doi: 10.1371/journal.pone.0059386

Chekabab, S. M., Daigle, F., Charette, S. J., Dozois, C. M., and Harel, J. (2012). Survival of enterohemorrhagic Escherichia coli in the presence of Acanthamoeba castellanii and its dependence on Pho regulon. Microbiologyopen 1, 427-437. doi: $10.1002 / \mathrm{mbo} 3.40$

Chen, C. Y., Hofmann, C. S., Cottrell, B. J., Strobaugh, T. P. Jr., Paoli, G. C., Nguyen, L. H., et al. (2013). Phenotypic and genotypic characterization of biofilm forming capabilities in non-O157 Shiga toxin-producing Escherichia coli strains. PLoS ONE 8:e84863. doi: 10.1371/journal.pone.0084863

Clements, A., Young, J. C., Constantinou, N., and Frankel, G. (2012). Infection strategies of enteric pathogenic Escherichia coli. Gut Microbes 3, 71-87. doi: 10.4161/gmic. 19182

Cookson, A. L., Cooley, W. A., and Woodward, M. J. (2002). The role of type 1 and curli fimbriae of Shiga toxin-producing Escherichia coli in adherence to abiotic surfaces. Int. J. Med. Microbiol. 292, 195-205. doi: 10.1078/1438-4221-00203

Cooper, I. R., Taylor, H. D., and Hanlon, G. W. (2007). Virulence traits associated with verocytotoxigenic Escherichia coli O157 recovered from freshwater biofilms. J. Appl. Microbiol. 102, 1293-1299. doi: 10.1111/j.13652672.2006.03178.x

Cornick, N. A., and Helgerson, A. F. (2004). Transmission and infectious dose of Escherichia coli O157:H7 in swine. Appl. Environ. Microbiol. 70, 5331-5335. doi: 10.1128/AEM.70.9.5331-5335.2004

Costerton, J. W., Stewart, P. S., and Greenberg, E. P. (1999). Bacterial biofilms: a common cause of persistent infections. Science 284, 1318-1322. doi: $10.1126 /$ science. 284.5418 .1318

Croxen, M. A., and Finlay, B. B. (2010). Molecular mechanisms of Escherichia coli pathogenicity. Nat. Rev. Microbiol. 8, 26-38. doi: 10.1038/nrmicro2265

Danese, P. N., Pratt, L. A., Dove, S. L., and Kolter, R. (2000). The outer membrane protein, antigen 43, mediates cell-to-cell interactions within Escherichia coli biofilms. Mol. Microbiol. 37, 424-432. doi: 10.1046/j.1365-2958.2000.02008.x

Dewanti, R., and Wong, A. C. (1995). Influence of culture conditions on biofilm formation by Escherichia coli O157:H7. Int. J. Food Microbiol. 26, 147-164. doi: 10.1016/0168-1605(94)00103-D

Dorel, C., Vidal, O., Prigent-Combaret, C., Vallet, I., and Lejeune, P. (1999). Involvement of the Cpx signal transduction pathway of E. coli in biofilm formation. FEMS Microbiol. Lett. 178, 169-175. doi: 10.1111/j.15746968.1999.tb13774.x

Dourou, D., Beauchamp, C. S., Yoon, Y., Geornaras, I., Belk, K. E., Smith, G. C., et al. (2011). Attachment and biofilm formation by Escherichia coli $\mathrm{O} 157: \mathrm{H} 7$ at different temperatures, on various food-contact surfaces encountered in beef processing. Int. J. Food. Microbiol. 149, 262-268. doi: 10.1016/j.ijfoodmicro.2011.07.004

Elder, R. O., Keen, J. E., Siragusa, G. R., Barkocy-Gallagher, G. A., Koohmaraie, M., and Laegreid, W. W. (2000). Correlation of enterohemorrhagic Escherichia coli O157 prevalence in feces, hides, and carcasses of beef cattle during processing. Proc. Natl. Acad. Sci. U.S.A. 97, 2999-3003. doi: 10.1073/pnas.97.7.2999
Etcheverria, A. I., and Padola, N. L. (2013). Shiga toxin-producing Escherichia coli: factors involved in virulence and cattle colonization. Virulence 4, 366-372. doi: 10.4161/viru. 24642

Farfan, M. J., and Torres, A. G. (2012). Molecular mechanisms that mediate colonization of Shiga toxin-producing Escherichia coli strains. Infect. Immun. 80, 903-913. doi: 10.1128/IAI.05907-11

Ferens, W. A., and Hovde, C. J. (2011). Escherichia coli O157:H7: animal reservoir and sources of human infection. Foodborne Pathog. Dis. 8, 465-487. doi: 10.1089/fpd.2010.0673

Fink, R. C., Black, E. P., Hou, Z., Sugawara, M., Sadowsky, M. J., and DiezGonzalez, F. (2012). Transcriptional responses of Escherichia coli K-12 and O157:H7 associated with lettuce leaves. Appl. Environ. Microbiol. 78, 1752-1764. doi: 10.1128/AEM.07454-11

Fletcher, M. (1988). Attachment of Pseudomonas fluorescens to glass and influence of electrolytes on bacterium-substratum separation distance. J. Bacteriol. 170, 2027-2030.

Fouladkhah, A., Geornaras, I., and Sofos, J. N. (2013). Biofilm formation of O157 and non-O157 Shiga toxin-producing Escherichia Coli and multidrug-resistant and susceptible Salmonella typhimurium and newport and their inactivation by sanitizers. J. Food Sci. 78, M880-M886. doi: 10.1111/1750-3841.12123

Frank, C., Werber, D., Cramer, J. P., Askar, M., Faber, M., An Der Heiden, M., et al. (2011). Epidemic profile of Shiga-toxin-producing Escherichia coli O104:H4 outbreak in Germany. N. Engl. J. Med. 365, 1771-1780. doi: 10.1056/NEJMoa1106483

Fukushima, H., Hashizume, T., Morita, Y., Tanaka, J., Azuma, K., Mizumoto, Y., et al. (1999). Clinical experiences in Sakai City Hospital during the massive outbreak of enterohemorrhagic Escherichia coli O157 infections in Sakai City, 1996. Pediatr. Int. 41, 213-217. doi: 10.1046/j.1442-200X.1999.4121041.x

Gagliardi, J. V., and Karns, J. S. (2000). Leaching of Escherichia coli O157:H7 in diverse soils under various agricultural management practices. Appl. Environ. Microbiol. 66, 877-883. doi: 10.1128/AEM.66.3.877-883.2000

Genevaux, P., Bauda, P., Dubow, M. S., and Oudega, B. (1999). Identification of Tn10 insertions in the $\mathrm{rfaG}, \mathrm{rfaP}$, and galU genes involved in lipopolysaccharide core biosynthesis that affect Escherichia coli adhesion. Arch. Microbiol. 172, 1-8. doi: 10.1007/s002030050732

Gerstel, U., Park, C., and Romling, U. (2003). Complex regulation of csgD promoter activity by global regulatory proteins. Mol. Microbiol. 49, 639-654. doi: 10.1046/j.1365-2958.2003.03594.x

Giaouris, E., Heir, E., Hebraud, M., Chorianopoulos, N., Langsrud, S., Moretro, T., et al. (2013). Attachment and biofilm formation by foodborne bacteria in meat processing environments: causes, implications, role of bacterial interactions and control by alternative novel methods. Meat Sci. 97, 298-309. doi: 10.1016/j.meatsci.2013.05.023

Gibson, H., Taylor, J. H., Hall, K. E., and Holah, J. T. (1999). Effectiveness of cleaning techniques used in the food industry in terms of the removal of bacterial biofilms. J. Appl. Microbiol. 87, 41-48. doi: 10.1046/j.1365-2672.1999.00790.x

Gill, C. O., and McGinnis, J. C. (2000). Contamination of beef trimmings with Escherichia coli during a carcass breaking process. Food Res. Int. 33, 125-130. doi: 10.1016/S0963-9969(00)00026-0

Gill, C. O., McGinnis, J. C., and Bryant, J. (2001). Contamination of beef chucks with Escherichia coli during carcass breaking. J. Food. Prot. 64, 1824-1827.

Gottesman, S., and Stout, V. (1991). Regulation of capsular polysaccharide synthesis in Escherichia coli K12. Mol. Microbiol. 5, 1599-1606. doi: 10.1111/j.13652958.1991.tb01906.x

Gourabathini, P., Brandl, M. T., Redding, K. S., Gunderson, J. H., and Berk, S. G. (2008). Interactions between food-borne pathogens and protozoa isolated from lettuce and spinach. Appl. Environ. Microbiol. 74, 2518-2525. doi: 10.1128/AEM.02709-07

Grant, J., Wendelboe, A. M., Wendel, A., Jepson, B., Torres, P., Smelser, C., et al. (2008). Spinach-associated Escherichia coli O157:H7 outbreak, Utah and New Mexico, 2006. Emerg. Infect. Dis. 14, 1633-1636. doi: 10.3201/eid1410.071341

Gualdi, L., Tagliabue, L., Bertagnoli, S., Ierano, T., De Castro, C., and Landini, P. (2008). Cellulose modulates biofilm formation by counteracting curli-mediated colonization of solid surfaces in Escherichia coli. Microbiology 154, 2017-2024. doi: 10.1099/mic.0.2008/018093-0

Habimana, O., Heir, E., Langsrud, S., Asli, A. W., and Moretro, T. (2010). Enhanced surface colonization by Escherichia coli O157:H7 in biofilms formed by an Acinetobacter calcoaceticus isolate from meat-processing environments. Appl. Environ. Microbiol. 76, 4557-4559. doi: 10.1128/AEM.02707-09 
Hall-Stoodley, L., and Stoodley, P. (2009). Evolving concepts in biofilm infections. Cell Microbiol. 11, 1034-1043. doi: 10.1111/j.1462-5822.2009.01323.x

Hammar, M., Arnqvist, A., Bian, Z., Olsen, A., and Normark, S. (1995). Expression of two csg operons is required for production of fibronectin- and congo redbinding curli polymers in Escherichia coli K-12. Mol. Microbiol. 18, 661-670. doi: 10.1111/j.1365-2958.1995.mmi_18040661.x

Hayashi, T., Makino, K., Ohnishi, M., Kurokawa, K., Ishii, K., Yokoyama, K., et al. (2001). Complete genome sequence of enterohemorrhagic Escherichia coli O157:H7 and genomic comparison with a laboratory strain K-12. DNA Res. 8, 11-22. doi: 10.1093/dnares/8.1.11

Herold, S., Paton, J. C., and Paton, A. W. (2009). Sab, a novel autotransporter of locus of enterocyte effacement-negative shiga-toxigenic Escherichia coli O113:H21, contributes to adherence and biofilm formation. Infect. Immun. 77, 3234-3243. doi: 10.1128/IAI.00031-09

Heuvelink, A. E., Zwartkruis-Nahuis, J. T., Van Den Biggelaar, F. L., Van Leeuwen, W. J., and De Boer, E. (1999). Isolation and characterization of verocytotoxinproducing Escherichia coli $\mathrm{O} 157$ from slaughter pigs and poultry. Int. J. Food Microbiol. 52, 67-75. doi: 10.1016/S0168-1605(99)00119-1

Hou, S., Liu, Z., Young, A. W., Mark, S. L., Kallenbach, N. R., and Ren, D. (2010). Effects of Trp- and Arg-containing antimicrobial-peptide structure on inhibition of Escherichia coli planktonic growth and biofilm formation. Appl. Environ. Microbiol. 76, 1967-1974. doi: 10.1128/AEM.02321-09

Hou, Z., Fink, R. C., Sugawara, M., Diez-Gonzalez, F., and Sadowsky, M. J. (2013). Transcriptional and functional responses of Escherichia coli O157:H7 growing in the lettuce rhizoplane. Food Microbiol. 35, 136-142. doi: 10.1016/j.fm.2013.03.002

Houari, A., and Di Martino, P. (2007). Effect of chlorhexidine and benzalkonium chloride on bacterial biofilm formation. Lett. Appl. Microbiol. 45, 652-656. doi: 10.1111/j.1472-765X.2007.02249.x

Ibekwe, A. M., Papiernik, S. K., Grieve, C. M., and Yang, C. H. (2011). Quantification of persistence of Escherichia coli O157:H7 in contrasting soils. Int. J. Microbiol. 2011:421379. doi: 10.1155/2011/421379

Jacques, M., Aragon, V., and Tremblay, Y. D. (2010). Biofilm formation in bacterial pathogens of veterinary importance. Anim. Health Res. Rev. 11, 97-121. doi: $10.1017 /$ S1466252310000149

Jeter, C., and Matthysse, A. G. (2005). Characterization of the binding of diarrheagenic strains of E. coli to plant surfaces and the role of curli in the interaction of the bacteria with alfalfa sprouts. Mol. Plant Microbe Interact. 18, 1235-1242. doi: 10.1094/MPMI-18-1235

Jubelin, G., Vianney, A., Beloin, C., Ghigo, J. M., Lazzaroni, J. C., Lejeune, P., et al. (2005). CpxR/OmpR interplay regulates curli gene expression in response to osmolarity in Escherichia coli. J. Bacteriol. 187, 2038-2049. doi: 10.1128/JB.187.6.2038-2049.2005

Kaper, J. B., Nataro, J. P., and Mobley, H. L. (2004). Pathogenic Escherichia coli. Nat. Rev. Microbiol. 2, 123-140. doi: 10.1038/nrmicro818

Kaplan, J. B. (2010). Biofilm dispersal: mechanisms, clinical implications, and potential therapeutic uses. J. Dent. Res. 89, 205-218. doi: $10.1177 / 0022034509359403$

Karmali, M. A., Mascarenhas, M., Shen, S., Ziebell, K., Johnson, S., Reid-Smith, R., et al. (2003). Association of genomic O-island 122 of Escherichia coli EDL 933 with verocytotoxin-producing Escherichia coli seropathotypes that are linked to epidemic and/or serious disease. J. Clin. Microbiol. 41, 4930-4940. doi: 10.1128/JCM.41.11.4930-4940.2003

Kikuchi, T., Mizunoe, Y., Takade, A., Naito, S., and Yoshida, S. (2005). Curli fibers are required for development of biofilm architecture in Escherichia coli K-12 and enhance bacterial adherence to human uroepithelial cells. Microbiol. Immunol. 49, 875-884. doi: 10.1111/j.1348-0421.2005.tb03678.x

Klayman, B. J., Volden, P. A., Stewart, P. S., and Camper, A. K. (2009). Escherichia coli O157:H7 requires colonizing partner to adhere and persist in a capillary flow cell. Environ. Sci. Technol. 43, 2105-2111. doi: 10.1021/es802218q

Knutton, S., Shaw, R. K., Anantha, R. P., Donnenberg, M. S., and Zorgani, A. A. (1999). The type IV bundle-forming pilus of enteropathogenic Escherichia coli undergoes dramatic alterations in structure associated with bacterial adherence, aggregation and dispersal. Mol. Microbiol. 33, 499-509. doi: 10.1046/j.13652958.1999.01495.x

Koutsoumanis, K. P., and Sofos, J. N. (2004). Comparative acid stress response of Listeria monocytogenes, Escherichia coli O157:H7 and Salmonella Typhimurium after habituation at different $\mathrm{pH}$ conditions. Lett. Appl. Microbiol. 38, 321-326. doi: $10.1111 /$ j.1472-765X.2004.01491.x
La Ragione, R. M., Best, A., Woodward, M. J., and Wales, A. D. (2009). Escherichia coli O157:H7 colonization in small domestic ruminants. FEMS Microbiol. Rev. 33, 394-410. doi: 10.1111/j.1574-6976.2008.00138.x

Lee, J. H., Kim, Y. G., Cho, M. H., Wood, T. K., and Lee, J. (2011). Transcriptomic analysis for genetic mechanisms of the factors related to biofilm formation in Escherichia coli O157:H7. Curr. Microbiol. 62, 1321-1330. doi: 10.1007/s00284010-9862-4

Lequette, Y., Boels, G., Clarisse, M., and Faille, C. (2010). Using enzymes to remove biofilms of bacterial isolates sampled in the food-industry. Biofouling 26, 421-431. doi: 10.1080/08927011003699535

Lewis, K. (2010). Persister cells. Annu. Rev. Microbiol. 64, 357-372. doi: 10.1146/annurev.micro.112408.134306

Liu, N. T., Nou, X., Lefcourt, A. M., Shelton, D. R., and Lo, Y. M. (2014). Dual-species biofilm formation by Escherichia coli O157:H7 and environmental bacteria isolated from fresh-cut processing facilities. Int. J. Food Microbiol. 171, 15-20. doi: 10.1016/j.ijfoodmicro.2013.11.007

Lu, L., Hume, M. E., and Pillai, S. D. (2005). Autoinducer-2-like activity on vegetable produce and its potential involvement in bacterial biofilm formation on tomatoes. Foodborne Pathog. Dis. 2, 242-249. doi: 10.1089/fpd. 2005.2.242

Maal-Bared, R., Bartlett, K. H., Bowie, W. R., and Hall, E. R. (2013). Phenotypic antibiotic resistance of Escherichia coli and E. coli O157 isolated from water, sediment and biofilms in an agricultural watershed in British Columbia. Sci. Total Environ. 443, 315-323. doi: 10.1016/j.scitotenv.2012.10.106

Macarisin, D., Patel, J., Bauchan, G., Giron, J. A., and Sharma, V. K. (2012). Role of curli and cellulose expression in adherence of Escherichia coli O157:H7 to spinach leaves. Foodborne Pathog. Dis. 9, 160-167. doi: 10.1089/fpd.2011.1020

Manning, S. D., Motiwala, A. S., Springman, A. C., Qi, W., Lacher, D. W., Ouellette, L. M., et al. (2008). Variation in virulence among clades of Escherichia coli O157:H7 associated with disease outbreaks. Proc. Natl. Acad. Sci. U.S.A. 105, 4868-4873. doi: 10.1073/pnas.0710834105

Marouani-Gadri, N., Augier, G., and Carpentier, B. (2009a). Characterization of bacterial strains isolated from a beef-processing plant following cleaning and disinfection-influence of isolated strains on biofilm formation by Sakai and EDL 933 E. coli O157:H7. Int. J. Food Microbiol. 133, 62-67. doi: 10.1016/j.ijfoodmicro.2009.04.028

Marouani-Gadri, N., Chassaing, D., and Carpentier, B. (2009b). Comparative evaluation of biofilm formation and tolerance to a chemical shock of pathogenic and nonpathogenic Escherichia coli O157:H7 strains. J. Food Prot. 72, 157-164.

Marouani-Gadri, N., Firmesse, O., Chassaing, D., Sandris-Nielsen, D., Arneborg, N., and Carpentier, B. (2010). Potential of Escherichia coli O157:H7 to persist and form viable but non-culturable cells on a food-contact surface subjected to cycles of soiling and chemical treatment. Int. J. Food Microbiol. 144, 96-103. doi: 10.1016/j.ijfoodmicro.2010.09.002

Matthysse, A. G., Deora, R., Mishra, M., and Torres, A. G. (2008). Polysaccharides cellulose, poly-beta-1,6-n-acetyl-D-glucosamine, and colanic acid are required for optimal binding of Escherichia coli O157:H7 strains to alfalfa sprouts and K-12 strains to plastic but not for binding to epithelial cells. Appl. Environ. Microbiol. 74, 2384-2390. doi: 10.1128/AEM.01854-07

Mauro, S. A., Opalko, H., Lindsay, K., Colon, M. P., and Koudelka, G. B. (2013). The microcosm mediates the persistence of shiga toxin-producing Escherichia coli in freshwater ecosystems. Appl. Environ. Microbiol. 79, 4821-4828. doi: 10.1128/AEM.01281-13

Mellor, G. E., Besser, T. E., Davis, M. A., Beavis, B., Jung, W., Smith, H. V., et al. (2013). Multilocus genotype analysis of Escherichia coli O157 isolates from Australia and the United States provides evidence of geographic divergence. Appl. Environ. Microbiol. 79, 5050-5058. doi: 10.1128/AEM.01525-13

Moreira, S., Brown, A., Ha, R., Iserhoff, K., Yim, M., Yang, J., et al. (2012). Persistence of Escherichia coli in freshwater periphyton: biofilm-forming capacity as a selective advantage. FEMS Microbiol. Ecol. 79, 608-618. doi: 10.1111/j.1574-6941.2011.01244.x

Nesse, L. L., Sekse, C., Berg, K., Johannesen, K. C., Solheim, H., Vestby, L. K., et al. (2013). Potentially pathogenic E. coli can produce biofilm under conditions relevant for the food production chain. Appl. Environ. Microbiol. 80, 2042-2049. doi: 10.1128/AEM.03331-13

Olsen, A., Jonsson, A., and Normark, S. (1989). Fibronectin binding mediated by a novel class of surface organelles on Escherichia coli. Nature 338, 652-655. doi: $10.1038 / 338652 \mathrm{a} 0$ 
Park, S. H., Cheon, H. L., Park, K. H., Chung, M. S., Choi, S. H., Ryu, S., et al. (2012). Inactivation of biofilm cells of foodborne pathogen by aerosolized sanitizers. Int. J. Food Microbiol. 154, 130-134. doi: 10.1016/j.ijfoodmicro.2011.12.018

Perez-Conesa, D., Cao, J., Chen, L., McLandsborough, L., and Weiss, J. (2011). Inactivation of Listeria monocytogenes and Escherichia coli O157:H7 biofilms by micelle-encapsulated eugenol and carvacrol. J. Food Prot. 74, 55-62. doi: 10.4315/0362-028X.JFP-08-403

Perez-Conesa, D., McLandsborough, L., and Weiss, J. (2006). Inhibition and inactivation of Listeria monocytogenes and Escherichia coli O157:H7 colony biofilms by micellar-encapsulated eugenol and carvacrol. J. Food Prot. 69, 2947-2954.

Perna, N. T., Plunkett, G. 3rd., Burland, V., Mau, B., Glasner, J. D., Rose, D. J., et al. (2001). Genome sequence of enterohaemorrhagic Escherichia coli O157:H7. Nature 409, 529-533. doi: 10.1038/35054089

Pratt, L. A., and Kolter, R. (1998). Genetic analysis of Escherichia coli biofilm formation: roles of flagella, motility, chemotaxis and type I pili. Mol. Microbiol. 30, 285-293. doi: 10.1046/j.1365-2958.1998.01061.x

Prigent-Combaret, C., Brombacher, E., Vidal, O., Ambert, A., Lejeune, P., Landini, P., et al. (2001). Complex regulatory network controls initial adhesion and biofilm formation in Escherichia coli via regulation of the csgD gene. J. Bacteriol. 183, 7213-7223. doi: 10.1128/JB.183.24.7213-7223.2001

Puttamreddy, S., Cornick, N. A., and Minion, F. C. (2010). Genome-wide transposon mutagenesis reveals a role for pO157 genes in biofilm development in Escherichia coli O157:H7 EDL933. Infect. Immun. 78, 2377-2384. doi: 10.1128/IAI.00156-10

Ravva, S. V., Sarreal, C. Z., and Mandrell, R. E. (2010). Identification of protozoa in dairy lagoon wastewater that consume Escherichia coli O157:H7 preferentially. PLoS ONE 5:e15671. doi: 10.1371/journal.pone.0015671

Ribeiro, A. F., Laroche, E., Hanin, G., Fournier, M., Quillet, L., Dupont, J. P., et al. (2012). Antibiotic-resistant Escherichia coli in karstic systems: a biological indicator of the origin of fecal contamination? FEMS Microbiol. Ecol. 81, 267-280. doi: 10.1111/j.1574-6941.2012.01382.x

Rivera-Betancourt, M., Shackelford, S. D., Arthur, T. M., Westmoreland, K. E., Bellinger, G., Rossman, M., et al. (2004). Prevalence of Escherichia coli O157:H7, Listeria monocytogenes, and Salmonella in two geographically distant commercial beef processing plants in the United States. J. Food Prot. 67, 295-302.

Roe, A. J., Currie, C., Smith, D. G., and Gally, D. L. (2001). Analysis of type 1 fimbriae expression in verotoxigenic Escherichia coli: a comparison between serotypes O157 and O26. Microbiology 147, 145-152.

Ryu, J. H., and Beuchat, L. R. (2005). Biofilm formation by Escherichia coli O157:H7 on stainless steel: effect of exopolysaccharide and Curli production on its resistance to chlorine. Appl. Environ. Microbiol. 71, 247-254. doi: 10.1128/AEM.71.1.247-254.2005

Ryu, J. H., Kim, H., and Beuchat, L. R. (2004a). Attachment and biofilm formation by Escherichia coli $\mathrm{O} 157: \mathrm{H} 7$ on stainless steel as influenced by exopolysaccharide production, nutrient availability, and temperature. J. Food Prot. 67, 2123-2131.

Ryu, J. H., Kim, H., Frank, J. F., and Beuchat, L. R. (2004b). Attachment and biofilm formation on stainless steel by Escherichia coli $\mathrm{O} 157: \mathrm{H} 7$ as affected by curli production. Lett. Appl. Microbiol. 39, 359-362. doi: 10.1111/j.1472765X.2004.01591.X

Schauder, S., Shokat, K., Surette, M. G., and Bassler, B. L. (2001). The LuxS family of bacterial autoinducers: biosynthesis of a novel quorum-sensing signal molecule. Mol. Microbiol. 41, 463-476. doi: 10.1046/j.1365-2958.2001.02532.x

Schembri, M. A., Dalsgaard, D., and Klemm, P. (2004). Capsule shields the function of short bacterial adhesins. J. Bacteriol. 186, 1249-1257. doi: 10.1128/JB.186.5.1249-1257.2004

Scheutz, F., Nielsen, E. M., Frimodt-Moller, J., Boisen, N., Morabito, S., Tozzoli, R., et al. (2011). Characteristics of the enteroaggregative Shiga toxin/verotoxinproducing Escherichia coli O104:H4 strain causing the outbreak of haemolytic uraemic syndrome in Germany, May to June 2011. Euro Surveill. 16, 5-10.

Seo, K. H., and Frank, J. F. (1999). Attachment of Escherichia coli O157:H7 to lettuce leaf surface and bacterial viability in response to chlorine treatment as demonstrated by using confocal scanning laser microscopy. J. Food Prot. 62, 3-9.

Sharma, M., Ryu, J. H., and Beuchat, L. R. (2005). Inactivation of Escherichia coli O157:H7 in biofilm on stainless steel by treatment with an alkaline cleaner and a bacteriophage. J. Appl. Microbiol. 99, 449-459. doi: 10.1111/j.13652672.2005.02659.x
Sharma, V. K., Bearson, S. M., and Bearson, B. L. (2010). Evaluation of the effects of sdiA, a luxR homologue, on adherence and motility of Escherichia coli O157: H7. Microbiology 156, 1303-1312. doi: 10.1099/mic.0.034330-0

Sheikh, J., Czeczulin, J. R., Harrington, S., Hicks, S., Henderson, I. R., Le Bouguenec, C., et al. (2002). A novel dispersin protein in enteroaggregative Escherichia coli. J. Clin. Invest. 110, 1329-1337. doi: 10.1172/JCI16172

Shifrin, Y., Peleg, A., Ilan, O., Nadler, C., Kobi, S., Baruch, K., et al. (2008). Transient shielding of intimin and the type III secretion system of enterohemorrhagic and enteropathogenic Escherichia coli by a group 4 capsule. J. Bacteriol. 190, 5063-5074. doi: 10.1128/JB.00440-08

Shringi, S., Garcia, A., Lahmers, K. K., Potter, K. A., Muthupalani, S., Swennes, A. G., et al. (2012). Differential virulence of clinical and bovine-biased enterohemorrhagic Escherichia coli O157:H7 genotypes in piglet and Dutch belted rabbit models. Infecti. Immun. 80, 369-380. doi: 10.1128/IAI.05470-11

Silagyi, K., Kim, S. H., Lo, Y. M., and Wei, C. I. (2009). Production of biofilm and quorum sensing by Escherichia coli O157:H7 and its transfer from contact surfaces to meat, poultry, ready-to-eat deli, and produce products. Food Microbiol. 26, 514-519. doi: 10.1016/j.fm.2009.03.004

Solheim, H. T., Sekse, C., Urdahl, A. M., Wasteson, Y., and Nesse, L. L. (2013). Biofilm as an environment for dissemination of stx genes by transduction. Appl. Environ. Microbiol. 79, 896-900. doi: 10.1128/AEM.03512-12

Solomon, E. B., Yaron, S., and Matthews, K. R. (2002). Transmission of Escherichia coli $\mathrm{O} 157: \mathrm{H} 7$ from contaminated manure and irrigation water to lettuce plant tissue and its subsequent internalization. Appl. Environ. Microbiol. 68, 397-400. doi: 10.1128/AEM.68.1.397-400.2002

Steinberg, K. M., and Levin, B. R. (2007). Grazing protozoa and the evolution of the Escherichia coli O157:H7 Shiga toxin-encoding prophage. Proc. Biol. Sci. 274, 1921-1929. doi: 10.1098/rspb.2007.0245

Stopforth, J. D., Samelis, J., Sofos, J. N., Kendall, P. A., and Smith, G. C. (2003). Influence of extended acid stressing in fresh beef decontamination runoff fluids on sanitizer resistance of acid-adapted Escherichia coli O157:H7 in biofilms. J. Food Prot. 66, 2258-2266.

Thomassin, J. L., Brannon, J. R., Gibbs, B. F., Gruenheid, S., and Le Moual, H. (2012). OmpT outer membrane proteases of enterohemorrhagic and enteropathogenic Escherichia coli contribute differently to the degradation of human LL-37. Infect. Immun. 80, 483-492. doi: 10.1128/IAI.05674-11

Thomassin, J. L., Lee, M. J., Brannon, J. R., Sheppard, D. C., Gruenheid, S., and Le Moual, H. (2013). Both group 4 capsule and lipopolysaccharide O-antigen contribute to enteropathogenic Escherichia coli resistance to human alpha-defensin 5. PLoS ONE 8:e82475. doi: 10.1371/journal.pone.0082475

Torres, A.G., Perna, N. T., Burland, V., Ruknudin, A., Blattner, F. R., and Kaper, J. B. (2002). Characterization of Cah, a calcium-binding and heat-extractable autotransporter protein of enterohaemorrhagic Escherichia coli. Mol. Microbiol. 45, 951-966. doi: 10.1046/j.1365-2958.2002.03094.x

Tutenel, A. V., Pierard, D., Van Hoof, J., Cornelis, M., and De Zutter, L. (2003). Isolation and molecular characterization of Escherichia coli $\mathrm{O} 157$ isolated from cattle, pigs and chickens at slaughter. Int. J. Food Microbiol. 84, 63-69. doi: 10.1016/S0168-1605(02)00395-1

Tyler, H. L., and Triplett, E. W. (2008). Plants as a habitat for beneficial and/or human pathogenic bacteria. Annu. Rev. Phytopathol. 46, 53-73. doi: 10.1146/annurev.phyto.011708.103102

Uhlich, G. A., Cooke, P. H., and Solomon, E. B. (2006). Analyses of the red-dryrough phenotype of an Escherichia coli O157:H7 strain and its role in biofilm formation and resistance to antibacterial agents. Appl. Environ. Microbiol. 72, 2564-2572. doi: 10.1128/AEM.72.4.2564-2572.2006

Uhlich, G. A., Rogers, D. P., and Mosier, D. A. (2010). Escherichia coli serotype O157:H7 retention on solid surfaces and peroxide resistance is enhanced by dual-strain biofilm formation. Foodborne Pathog. Dis. 7, 935-943. doi: 10.1089/fpd.2009.0503

Van Elsas, J. D., Semenov, A. V., Costa, R., and Trevors, J. T. (2011). Survival of Escherichia coli in the environment: fundamental and public health aspects. ISME J. 5, 173-183. doi: 10.1038/ismej.2010.80

Van Overbeek, L. S., Franz, E., Semenov, A. V., De Vos, O. J., and Van Bruggen, A. H. (2010). The effect of the native bacterial community structure on the predictability of E. coli O157:H7 survival in manure-amended soil. Lett. Appl. Microbiol. 50, 425-430. doi: 10.1111/j.1472-765X.2010.02817.x

Velarde, J. J., Varney, K. M., Inman, K. G., Farfan, M., Dudley, E., Fletcher, J., et al. (2007). Solution structure of the novel dispersin protein of 
enteroaggregative Escherichia coli. Mol. Microbiol. 66, 1123-1135. doi: 10.1111/j.1365-2958.2007.05985.x

Verstraete, K., De Reu, K., Van Weyenberg, S., Pierard, D., De Zutter, L., Herman, L., et al. (2013). Genetic characteristics of Shiga toxin-producing E. coli O157, O26, O103, O111 and O145 isolates from humans, food, and cattle in Belgium. Epidemiol. Infect. 141, 2503-2515. doi: 10.1017/S095026881 3000307

Vianney, A., Jubelin, G., Renault, S., Dorel, C., Lejeune, P., and Lazzaroni, J. C. (2005). Escherichia coli tol and rcs genes participate in the complex network affecting curli synthesis. Microbiology 151, 2487-2497. doi: 10.1099/mic.0.27913-0

Vidal, O., Longin, R., Prigent-Combaret, C., Dorel, C., Hooreman, M., and Lejeune, P. (1998). Isolation of an Escherichia coli K-12 mutant strain able to form biofilms on inert surfaces: involvement of a new ompR allele that increases curli expression. J. Bacteriol. 180, 2442-2449.

Vidovic, S., Block, H. C., and Korber, D. R. (2007). Effect of soil composition, temperature, indigenous microflora, and environmental conditions on the survival of Escherichia coli O157:H7. Can. J. Microbiol. 53, 822-829. doi: 10.1139/W07-041

Vikram, A., Jayaprakasha, G. K., Jesudhasan, P. R., Pillai, S. D., and Patil, B. S. (2010). Suppression of bacterial cell-cell signalling, biofilm formation and type III secretion system by citrus flavonoids. J. Appl. Microbiol. 109, 515-527. doi: 10.1111/j.1365-2672.2010.04677.x

Vu-Khac, H., and Cornick, N. A. (2008). Prevalence and genetic profiles of Shiga toxin-producing Escherichia coli strains isolated from buffaloes, cattle, and goats in central Vietnam. Vet. Microbiol. 126, 356-363. doi: 10.1016/j.vetmic.2007.07.023

Walters, M., and Sperandio, V. (2006). Quorum sensing in Escherichia coli and Salmonella. Int. J. Med. Microbiol. 296, 125-131. doi: 10.1016/j.ijmm.2006.01.041

Wang, R., Bono, J. L., Kalchayanand, N., Shackelford, S., and Harhay, D. M. (2012). Biofilm formation by Shiga toxin-producing Escherichia coli O157:H7 and Non-O157 strains and their tolerance to sanitizers commonly used in the food processing environment. J. Food. Prot. 75, 1418-1428. doi: 10.4315/0362028X.JFP-11-427

Welch, R. A., Burland, V., Plunkett, G., Redford, P., Roesch, P., Rasko, D., et al. (2002). Extensive mosaic structure revealed by the complete genome sequence of uropathogenic Escherichia coli. Proc. Natl. Acad. Sci. U.S.A. 99, 17020-17024. doi: 10.1073/pnas.252529799

Wells, T. J., McNeilly, T. N., Totsika, M., Mahajan, A., Gally, D. L., and Schembri, M. A. (2009). The Escherichia coli O157:H7 EhaB autotransporter protein binds to laminin and collagen I and induces a serum IgA response in O157:H7 challenged cattle. Environ. Microbiol. 11, 1803-1814. doi: 10.1111/j.14622920.2009.01905.x

Wells, T. J., Sherlock, O., Rivas, L., Mahajan, A., Beatson, S. A., Torpdahl, M., et al. (2008). EhaA is a novel autotransporter protein of enterohemorrhagic Escherichia coli O157:H7 that contributes to adhesion and biofilm formation. Environ. Microbiol. 10, 589-604. doi: 10.1111/j.1462-2920.2007. 01479.x
Wey, J. K., Jurgens, K., and Weitere, M. (2012). Seasonal and successional influences on bacterial community composition exceed that of protozoan grazing in river biofilms. Appl. Environ. Microbiol. 78, 2013-2024. doi: 10.1128/AEM.06517-11

Whitfield, C. (2006). Biosynthesis and assembly of capsular polysaccharides in Escherichia coli. Annu. Rev. Biochem. 75, 39-68. doi: 10.1146/annurev.biochem.75.103004.142545

Woerner, D. R., Ransom, J. R., Sofos, J. N., Dewell, G. A., Smith, G. C., Salman, M. D., et al. (2006). Determining the prevalence of Escherichia coli O157 in cattle and beef from the feedlot to the cooler. J. Food. Prot. 69, 2824-2827.

Wood, T. K. (2009). Insights on Escherichia coli biofilm formation and inhibition from whole-transcriptome profiling. Environ. Microbiol. 11, 1-15. doi: 10.1111/j.1462-2920.2008.01768.x

Yang, K., Meng, J., Huang, Y. C., Ye, L. H., Li, G. J., Huang, J., et al. (2014). The role of the QseC quorum-sensing sensor kinase in epinephrine-enhanced motility and biofilm formation by Escherichia coli. Cell Biochem. Biophys. doi: 10.1007/s12013-014-9924-5. [Epub ahead of print].

Yeh, J. Y., and Chen, J. (2004). Production of slime polysaccharide by EHEC and STEC as well as the influence of culture conditions on slime production in Escherichia coli O157:H7. Lett. Appl. Microbiol. 38, 488-492. doi: 10.1111/j.1472-765X.2004.01523.x

Zhang, W., Qi, W., Albert, T. J., Motiwala, A. S., Alland, D., Hyytia-Trees, E. K., et al. (2006). Probing genomic diversity and evolution of Escherichia coli O157 by single nucleotide polymorphisms. Genome Res. 16, 757-767. doi: 10.1101/gr.4759706

Zhang, Y., Laing, C., Zhang, Z., Hallewell, J., You, C., Ziebell, K., et al. (2010). Lineage and host source are both correlated with levels of Shiga toxin 2 production by Escherichia coli O157:H7 strains. Appl. Environ. Microbiol. 76, 474-482. doi: 10.1128/AEM.01288-09

Zogaj, X., Nimtz, M., Rohde, M., Bokranz, W., and Romling, U. (2001). The multicellular morphotypes of Salmonella typhimurium and Escherichia col produce cellulose as the second component of the extracellular matrix. Mol. Microbiol. 39, 1452-1463. doi: 10.1046/j.1365-2958.2001.02337.x

Conflict of Interest Statement: The authors declare that the research was conducted in the absence of any commercial or financial relationships that could be construed as a potential conflict of interest.

Received: 03 March 2014; accepted: 10 June 2014; published online: 01 July 2014. Citation: Vogeleer P, Tremblay YDN, Mafu AA, Jacques M and Harel J (2014) Life on the outside: role of biofilms in environmental persistence of Shiga-toxin producing Escherichia coli. Front. Microbiol. 5:317. doi: 10.3389/fmicb.2014.00317

This article was submitted to Microbial Physiology and Metabolism, a section of the journal Frontiers in Microbiology.

Copyright (c) 2014 Vogeleer, Tremblay, Mafu, Jacques and Harel. This is an openaccess article distributed under the terms of the Creative Commons Attribution License (CC BY). The use, distribution or reproduction in other forums is permitted, provided the original author(s) or licensor are credited and that the original publication in this journal is cited, in accordance with accepted academic practice. No use, distribution or reproduction is permitted which does not comply with these terms. 